\title{
ogopaedica
ogziensia
}

$\operatorname{Nr} 1$ (2017)

D0l: http://dx.doi.org/10.18778/2544-7238.01.14

Danuta Pluta-Wojciechowska*

\section{Komunikat z przebiegu V Międzynarodowej Konferencji Logopedycznej w Chorzowie (16-17 września 2017 r.)}

W dniach 16-17 września 2017 roku w Śląskim Międzyuczelnianym Centrum Edukacji i Badań Interdyscyplinarnych w Chorzowie odbyła się V Międzynarodowa Konferencja Logopedyczna pt. „Logopedia w teorii i praktyce”. Organizatorami konferencji były następujące instytucje: Instytut Języka Polskiego Uniwersytetu Śląskiego, Fundacja Wiedzy i Dialogu Społecznego Agere Aude, Zarząd Śląskiego Oddziału Polskiego Towarzystwa Logopedycznego, Wydział Zamiejscowy Nauk Humanistycznych i Społecznych Akademii Ignatianum w Krakowie, Śląskie Międzyuczelniane Centrum Edukacji i Badań Interdyscyplinarnych w Chorzowie.

Nadrzędnym celem konferencji była naukowa dyskusja na temat zaburzeń mowy, a także spotkanie logopedycznej teorii i praktyki. Podjęliśmy rozważania dotyczące teoretycznych podstaw diagnozy i terapii logopedycznej oraz dokonaliśmy rewizji niektórych praktycznych rozwiązań stosowanych podczas postępowania logopedycznego. Uznając tezę, że praktyka jest punktem wyjścia i inspiracją do badań naukowych, staraliśmy się zaprezentować najnowsze wyniki działalności naukowej logopedów. Aby zrealizować postawione cele, wykorzystaliśmy różne formy prezentacji treści naukowych: wykłady, postery, warsztaty.

Ważnym wątkiem naukowego spotkania była dyskusja dotycząca problemu, który określiliśmy za pomocą pytania: „Dokąd zmierza logopedia?”. Ten wątek dyskusji był szczególnie interesujący i - mamy nadzieję - inspirujący.

Wśród zaproszonych gości specjalnych znajdowały się uznane autorytety w zakresie logopedii z Belgii, Czech, USA, Rosji i Ukrainy, a także z Polski. Więcej informacji na temat konferencji można znaleźć na stronie: http://konferencjalogopedyczna.pl.

\footnotetext{
* Zakład Dialektologii Polskiej i Logopedii, Instytut Filologii Polskiej i Logopedii, Wydział Filologiczny Uniwersytetu Łódzkiego, ul. Pomorska 171/173, 90-236 Łódź, danuta@pluta-wojciechowska.eu.
} 